\title{
Notes on Polish polypores 4. Polyporus alveolaris
}

\author{
MARCIN PIĄTEK
}

PIĄTEK, M. 2004: Notes on Polish polypores 4. Polyporus alveolaris. - Karstenia 44: 61-66. Helsinki. ISSN 0453-3402.

\begin{abstract}
Abundant recent collections of Polyporus alveolaris (DC. : Fr.) Bondartsev \& Singer (Basidiomycota) help to outline the morphology, ecology and distribution of this rare, predominantly submediterranean polypore. The Polish localities are actually the northernmost ones in Europe, notably expanding the range of $P$. alveolaris. Eleven species of Polyporus are known in Poland.

Key words: ecology, Poland, Polyporus, taxonomy, wood-rotting fungi

Marcin Pitek, Department of Mycology, W. Szafer Institute of Botany, Polish Academy of Sciences, Lubicz 46, PL-31-512 Cracow, Poland; e-mail: mpiatek@ibpan.krakow.pl
\end{abstract}

\section{Introduction}

Polyporus alveolaris (DC. : Fr.) Bondartsev \& Singer is a species of warm-temperate climate, widely distributed throughout southern Europe, Asia and North America (Gilbertson \& Ryvarden 1987, Ryvarden \& Gilbertson 1994, Núñez \& Ryvarden 1995, 2001). In the monograph of Polish polypores, Domański et al. (1967) mentioned $P$. alveolaris among the species whose finding in Poland is hardly probable. However, some southern species have been found in Poland in subsequent years, for instance $P$. rhizophilus (Pat.) Sacc. and Oligoporus obductus (Berk.) Gilb. \& Ryvarden, as well as $P$. alveolaris. The map in Ryvarden and Gilbertson (1994) showed the species to exist in Poland, but this record was not accompanied with the reference of citation or herbarium specimen. It seems that the first published record of $P$. alveolaris in Poland, deriving from year 2000, was given by Friedrich and Orzechows$\mathrm{ka}$ (2002). However, this is not the sole collection of the fungus in the country since there are numerous unpublished findings of this species from 1995 onwards, collected in Tarnów town in southern Poland. My paper provides information on these collections. The morphology, ecology and distribution of $P$. alveolaris are here outlined based on specimens and observations from Poland.

\section{Taxonomy}

Polyporus alveolaris (DC. : Fr.) Bondartsev \& Singer Fig. 1

Ann. Mycol. 39: 58. 1941. - For synonyms, see Núñez and Ryvarden (1995).

Basidiome annual, sessile or short stipitate. $\mathrm{Pi}$ leus circular or flabelliform, up to $5 \mathrm{~cm}$ in diam. Upper surface smooth, glabrous, but with flattened, concentric squamules, orange-yellow, with age becoming cream-coloured to ivory and pale buff and resembling many other species. Edge concolorous, uneven, acute. Pore surface creamcoloured, pores large, hexagonal or pentagonal, 1-2 per mm. Context ivory coloured, azonate, corky, tubes concolorous with context. Stipe short, central or lateral, cream-coloured or ivory, up to 1 $\mathrm{cm}$ long. Hyphal system dimitic, generative hyphae thin-walled, hyaline, with clamps, moderately 

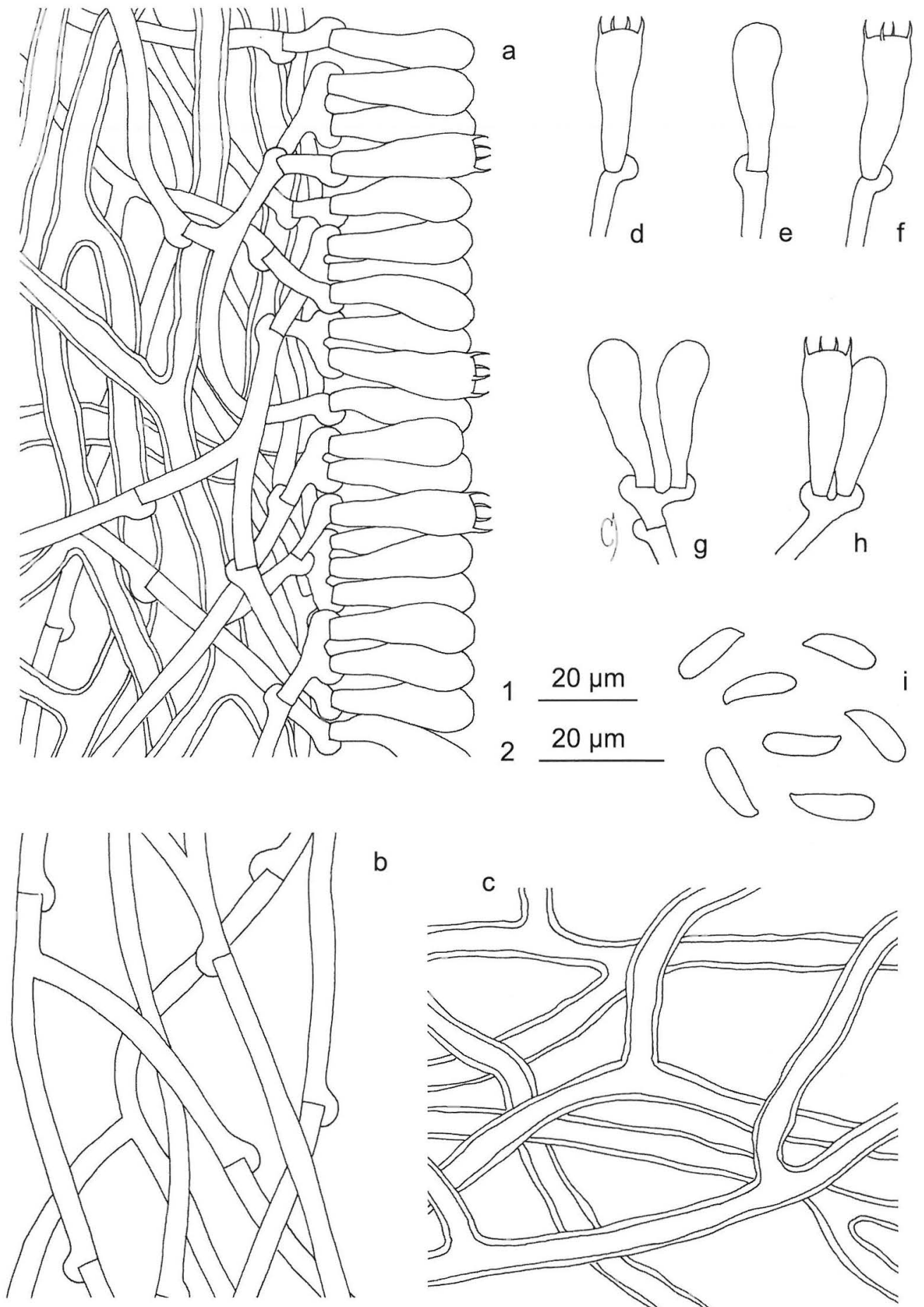

b

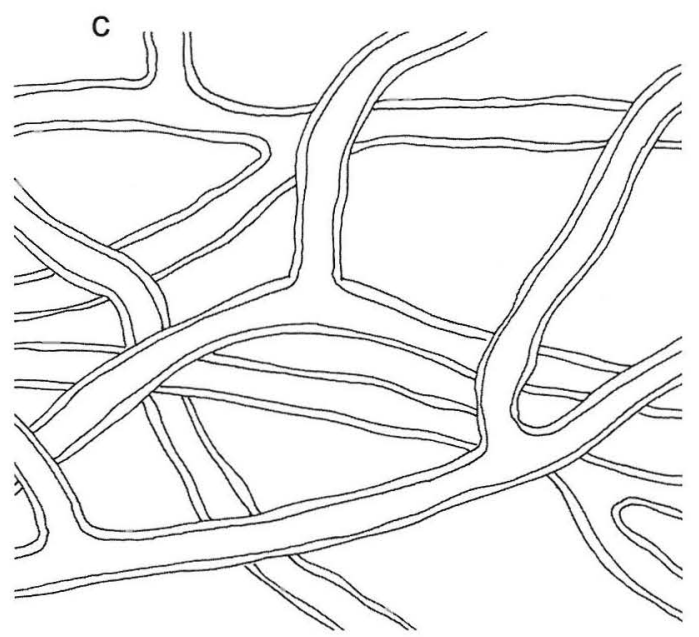

Fig. 1. Microscopical structures of Polyporus alveolaris (DC. : Fr.) Bondartsev \& Singer (drawn from KRAM F39490). - a) hymenium, b) generative hyphae, c) skeleto-binding hyphae, d-h) basidia, i) basidiospores. Use the scale 1 for $\mathrm{a}-\mathrm{h}$ and scale 2 for $\mathrm{i}$. 
branched, up to $4 \mu \mathrm{m}$ wide, skeleto-binding hyphae thick-walled, nonseptate, richly branched, up to $7 \mu \mathrm{m}$ wide. Cystidia or other similar sterile elements absent. Basidia clavate, with basal clamp and 4 sterigmata, 20-30 $\times 7-9 \mu \mathrm{m}$. Basidiospores cylindrical, hyaline, smooth, non amyloid, 10-13(14) $\times 3.5-5 \mu \mathrm{m}$.

Specimens examined: Poland. Małopolska Prov. Tarnów Distr., Tarnów: Park Kwiatkowskiego, fallen branch of deciduous tree $(4 \mathrm{~cm}), 6 . I X .1996$ Piątek (KRAM F-39230); at Akacjowa St., dead still attached branch of Syringa vulgaris, 12.IX.1996 Piątek (KRAM F-39213); Lasy Krzyskie (complex I, at Wiśniowa St.), Tilio cordatae-Carpinetum betuli, fallen branches of Acer platanoides $(0.5$ and $1.5 \mathrm{~cm}), 21 . I X .1999$ Piątek (KRAM F-39541), fallen branch of Fraxinus excelsior $(2 \mathrm{~cm})$, 8.IX.2000 Piątek (KRAM F-52161); Lasy Krzyskie (complex IC, at Wiśniowa St.), Tilio cordatae-Carpinetum betuli, fallen branch of Quercus rubra $(6 \mathrm{~cm})$, 10.V.1999 Piątek observation; Lasy Krzyskie (complex IIA, at Ścieżki St.), with $F$. excelsior and $Q$. rubra, fallen branches of $F$. excelsior ( 3 and $5 \mathrm{~cm}$ ), 10.V.1999 Piątek (KRAM F-39508, F-39509); Lasy Krzyskie (complex IIB, at Ścieżki St.), with $F$. excelsior and $Q$. rubra, fallen branch of F. excelsior (1cm), 26.VIII.1999 Pitek (KRAM F-39838); Lasy Krzyskie (complex III, at Kalinowa St.), with $F$. excelsior and $Q$. rubra, dead still attached branch of Q. rubra (2 cm), 10.V.1999 Piątek (KRAM F-39510); south of the Krzyskie Stawy ponds, humid alder forest, fallen branch of $F$. excelsior (5 cm), 20.IX.1999 Piątek (KRAM F-39737); Park Sanguszków, manor park, fallen branch of deciduous tree $(1 \mathrm{~cm}), 12 . I X .1995$ Piątek (KRAM F-39214); near ruins of the Tarnowskich Castle, tree stand, fallen branch of $F$. excelsior $(2 \mathrm{~cm})$,
6.IX.1997 Piątek observation; Góra Świętego Marcina, Tilio cordatae-Carpinetum betuli, fallen branch of A. platanoides $(1 \mathrm{~cm}), 13$.VIII.1997 Piątek (KRAM F-39229), fallen branch of $A$. platanoides $(4 \mathrm{~cm})$, 2.VII.1998 Piątek (KRAM F-39228), fallen branch of A. platanoides $(1 \mathrm{~cm}), 6 . I X .2002$ Piątek (KRAM F-52814), fallen branch of $F$. excelsior ( $2 \mathrm{~cm}$ ), 17.V.1999 Piątek observation, fallen branch of $F$. excelsior $(3 \mathrm{~cm})$, 17.V.1999 Piątek (KRAM F-39507); Pogórze Wiśnickie: Panieńska Góra Reserve, ca. $16 \mathrm{~km} \mathrm{SW}$ of Tarnów, Tilio cordatae-Carpinetum betuli, fallen branch of A. platanoides $(5 \mathrm{~cm}), 10$.VIII.1998 Piątek (KRAM F-39348).

\section{Discussion}

Polyporus alveolaris is a lignicolous species, restricted to deciduous wood. In Poland it was most often recorded on small branches 1 to $6 \mathrm{~cm}$ thick. Usually the basidiomes were growing on the upper side of branches lying on the ground, but sometimes the basidiomes emerged from dry branches still attached to the tree. The main host in the Polish populations of the fungus was Fraxinus excelsior followed by Acer platanoides, Quercus rubra and Syringa vulgaris (Fig. 2). Similar hosts were found for the fungus, e.g. in Switzerland (Breitenbach \& Kränzlin 1986), Italy (Bernicchia 1990) and the Czech Republic and Slovakia (Kotlaba 1984). However, in the latter area the most common hosts were maple trees Acer campestre and A. pseudoplatanus, but a few

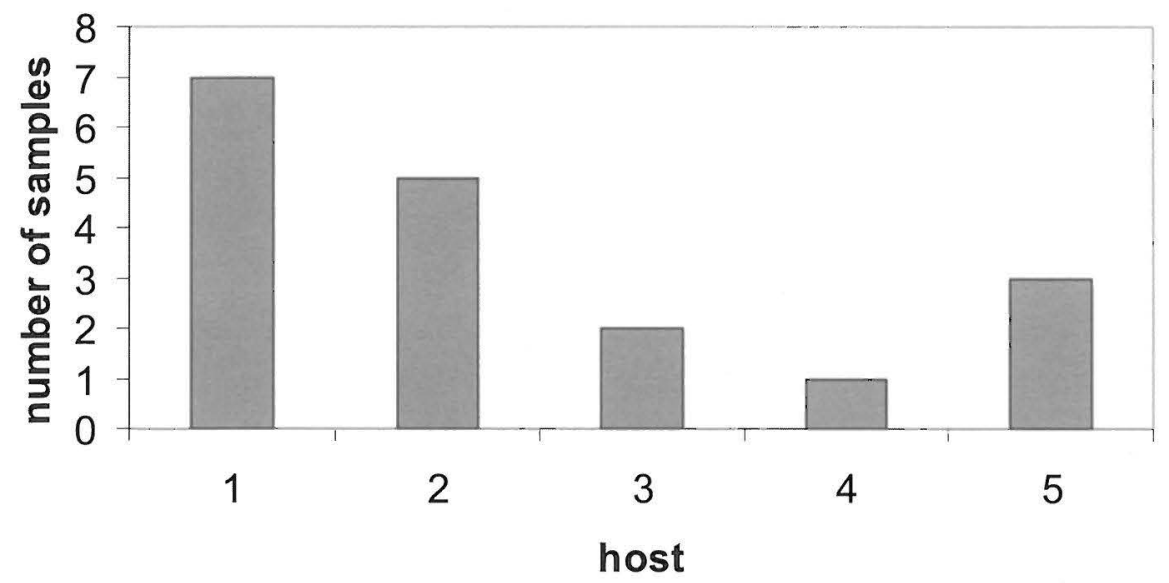

Fig. 2. Host spectrum for Polyporus alveolaris (DC. : Fr.) Bondartsev \& Singer in Poland. - 1) Fraxinus excelsior, 2) Acer platanoides, 3) Quercus rubra, 4) Syringa vulgaris, 5) unidentified deciduous tree. 
further specimens were collected, e.g., on ash (Fraxinus sp. and $F$. angustifolia ssp. danubialis) and lilac (Syringa vulgaris).

Polyporus alveolaris grew both in synanthropic, natural and semi-natural habitats. The sites affected by humans were parks and green belts. In such environments the fungus has been found four times, once in Szczecin (Friedrich \& Orzechowska 2002) and three times in Tarnów. Natural forests were mostly classified as the Tilio cordatae-Carpinetum betuli association, and rarely mesic herb-rich alder forests with the dominance of Fraxinus excelsior or semi-natural forest with the dominance of $F$. excelsior and Quercus rubra. In natural and semi-natural habitats $P$. alveolaris favoured fairly humid and sunny places.
Polyporus alveolaris started to form basidiomes already in May: from this month the number of collections is relatively high. However, the main fruiting period was in September. In other months the number of specimens is smaller, and for instance in June no collections were made.

In Europe Polyporus alveolaris shows a submediterranean type of distribution with maximal occurrence in the Mediterranean region, extending to the southern parts of Germany (Krieglsteiner 1991), the Czech Republic and Slovakia (Kotlaba 1984). In the light of the present study the occurrence of P. alveolaris in Tarnów at the northern border of the Carpathians (Fig. 3) is an isolated outlier, including one locality in the Panieńska Góra Reserve, 16 km south-west of Tarnów. The

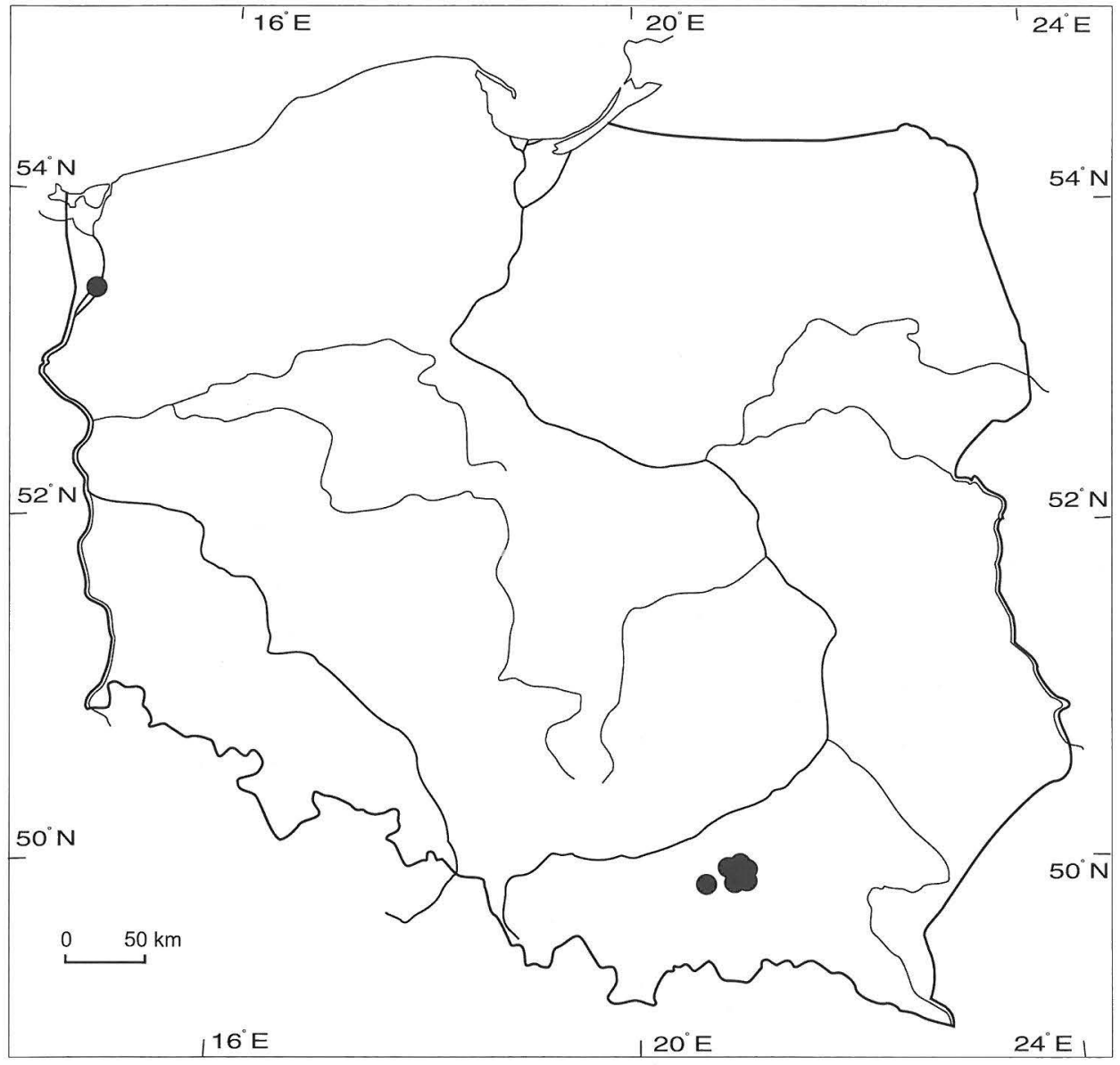

Fig. 3. Distribution of Polyporus alveolaris (DC. : Fr.) Bondartsev \& Singer in Poland. 
localities in Tarnów are mostly in northern and southern parts of the city in natural and seminatural forest complexes, while only two localities are in the parks and green belt in central part of the city (Fig. 4). The closest locality to these lays about $80 \mathrm{~km}$ south in eastern Slovakia on the southern slopes of the Carpathian chain. P. alveolaris has in southern Poland a limited occurrence; the species has not been found in Cracow, $80 \mathrm{~km}$ west from Tarnów, despite this city is well explored mycologically (Wojewoda 1991, 1996).

In Szczecin (Fig. 3) Polyporus alveolaris was found only once (Friedrich \& Orzechowska 2002). This locality is very isolated from the others in southern Germany and Poland, and hence it is very interesting. A similar isolated locality is known in northern Germany far from the main range of the species (Krieglsteiner 1991).

The number of basidiomes of Polyporus alveolaris varied greatly between the localities. Most abundant it was in Góra Świętego Marcina, where it formed numerous basidiomes from May to September. It was less frequent in other natural or semi-natural places, for instance in the Lasy Krzyskie in northern Tarnów or in the PanieDska Góra Reserve. In man-influenced places only single basidiomes were seen. However, it is hard to evaluate the red-list status of this fungus accord-

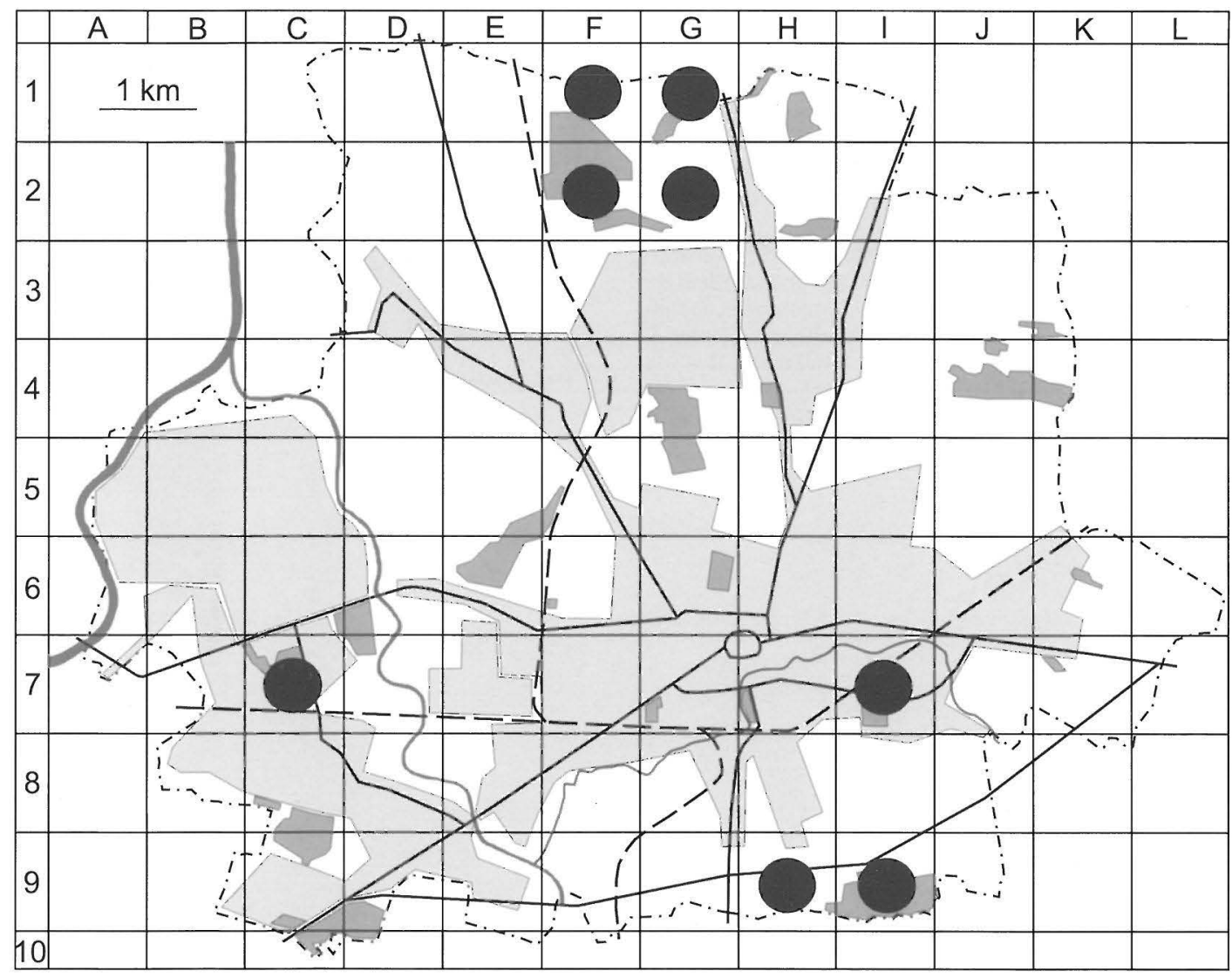

a

b
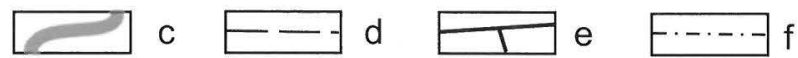

Fig. 4. Distribution of Polyporus alveolaris (DC. : Fr.) Bondartsev \& Singer in Tarnów town. - a) forests and parks, b) built-up area, c) rivers, d) railway, e) roads, f) town border. 
ing to the criteria of IUCN (2001) before long-term observations on the populations are available. Eleven species of Polyporus are known in Poland. Of these, common or rather common are $P$. brumalis (Pers.) Fr., P. ciliatus Fr. : Fr., P. squamosus (Huds.) Fr., and $P$. varius (Pers.) Fr., while others are rarely reported: $P$. arcularius (Batsch) Fr., $P$. badius (Pers.) Schwein., P. melanopus (Pers.) Fr., and $P$. umbellatus (Pers.) Fr. The remaining ones are very rare: $P$. alveolaris, $P$. rhizophilus (Pat.) Sacc. and P. tuberaster (Jacq.) Fr.

Acknowledgements: I warmly thank Dr. Tuomo Niemelä (Helsinki) for valuable suggestions on the manuscript and to Ms. Jolanta CabaBa (Cracow) for her illustrations. This study was supported by the Polish State Committee for Scientific Research (KBN grant 6 P04G 034 18).

\section{References}

Bernicchia, A. 1990: Polyporaceae s.1. in Italia. - Istituto di Patologia Vegetale, Bologna. 594 pp.

Breitenbach, J. \& Kränzlin, F. 1986: Fungi of Swizerland 2. Heterobasidiomycetes, Aphyllophorales, Gasteromycetes. - Mykologia, Luzern. 412 pp.

Domański, S., Orłoś, H. \& Skirgiełło, A. 1967: Basidiomycetes, Aphyllophorales, Polyporaceae pileatae, Mucronoporaceae pileatae, Ganodermataceae, Bondarzewiaceae, Boletopsidaceae, Fistulinaceae. - In: J. Kochman \& A. Skirgiełło (eds.), Flora Polska. Rośliny zarodnikowe Polski i ziem ościennych. Grzyby (Mycota) 3. Państwowe Wydawnictwo Naukowe, Warszawa. 398 pp. [In Polish].
Friedrich, S. \& Orzechowska, M. 2002: Macromycetes in the urban environment of Szczecin. - Badan. Fizjogr. Polsk. Zach., B (Botanika) 51: 7-30 [In Polish with English summary].

Gilbertson, R. L. \& Ryvarden, L. 1987: North American polypores. 2. Megasporoporia-Wrightoporia. - Fungiflora, Oslo. 435-885 pp.

IUCN 2001: IUCN red list categories and criteria: version 3.1. IUCN Species Survival Commission. - IUCN, Gland, and Cambridge, II + 30 pp.

Kotlaba, F. 1984: Geographical distribution and ecology of polypores (Polyporales s. 1.) in Czechoslovakia. Academia, Praha. 194 pp. +123 maps [In Czech with English summary].

Krieglsteiner, G. J. 1991: Verbreitungsatlas der Grosspilze Deutschlands (West) 1. Ständerpilze (A). Nichtblätterpilze. - E. Ulmer, Stuttgart. VI + 416 pp.

Núñez, M. \& Ryvarden, L. 1995: Polyporus (Basidiomycotina) and related genera. - Synopsis Fungorum 10: $1-85$.

Núñez, M. \& Ryvarden, L. 2001: East Asian polypores 2. Polyporaceae s. lato. - Synopsis Fungorum 14: V + $170-522$.

Ryvarden, L. \& Gilbertson, R. L. 1994: European polypores 2. Meripilus-Tyromyces. - Synopsis Fungorum 7: 389-743.

Wojewoda, W. 1991: Changes in macrofungal flora of Cracow (S. Poland). - In: K. Zarzycki, E. Landolt \& J. J. Wójcicki (eds.), Contribution to the knowledge of flora and vegetation of Poland. - Veröff. Geobot. Inst. ETH, Stiftung Rübel, Zürich 106: 150-161.

Wojewoda, W. 1996: Fungi of Cracow during the years 1883-1994 with particular interest in macrofungi. Studia Ośr. Dokument Fizjogr. PAN 24: 75-111 [In Polish with English summary]. 